\title{
Synthesis, Spectral Characterization and Biological Screening of Potentially Active 1, 3-Diones and its Transition Metal Complexes
}

\author{
D. M. SURYAWANSHI ${ }^{1}$, V. D. INGLE, N. A. BHISE, \\ A. S. RAJBHOJ ${ }^{2}$ and S. T. GAIKWAD ${ }^{2 *}$ \\ ${ }^{1}$ Department of Chemistry, Rayat Shikshan Sanstha's Annasaheb Awate College, \\ Manchar (M.S.), 410 503, India \\ ${ }^{2}$ Department of Chemistry, Dr. Babasaheb Ambedkar Marathwada University, \\ Aurangabad (M.S.), 431 004, India \\ gaikwadsuresh12@gmail.com
}

Received 4 June 2016 / Accepted 26 June 2016

\begin{abstract}
Hydroxyphenyl)-3-propane-1, 3-diones $\mathbf{4}\left(\mathbf{L}_{\mathbf{A}}-\mathbf{L}_{\mathbf{B}}\right)$ and its metal complexes $\mathbf{5}(\mathbf{a}-\mathbf{e})$ have been newly synthesized from substituted 2-hydroxyacetophenones 1(A-B) and aromatic acids 2(A-B) under ultrasound irradiation method at low temperature. These compounds were characterized by FT-IR, UV-Vis., ${ }^{1} \mathrm{H}-\mathrm{NMR},{ }^{13} \mathrm{C}-\mathrm{NMR}$, mass spectroscopy and magnetic measurement. The stoichiometry of the complexes was found 1:2 (metal:ligand). The physicochemical data suggested octahedral geometry for all the complexes. The ligands $\mathbf{4}\left(\mathbf{L}_{\mathbf{A}}-\mathbf{L}_{\mathbf{B}}\right)$ and their metal complexes $\mathbf{5}(\mathbf{a}-\mathbf{e})$ were screened for in vitro antibacterial activity against $S$. aureus, B. subtilis, E. coli and P. aeruginosa compared with tetracycline and chloramphenicol as a standard drugs. The results are in good agreement with respect to activity of free ligand and its metal complexes. Reactions under ultrasonic irradiation had improved yield.
\end{abstract}

Keywords: 1, 3-Diones, Metal complexes, Ultrasound irradiations, Magnetic measurements, Antibacterial screening

\section{Introduction}

1, 3-Diones have broad spectrum of medicinal values which shown to have pharmacological activity like antibacterial ${ }^{1}$, antiviral ${ }^{2}$, insecticidal ${ }^{3}$, antioxidant ${ }^{4}$ and potential prophylactic antitumor activity ${ }^{5,6}$. It has also been used in the anti-sunscreen agent ${ }^{7}$. In liquid solutions ${ }^{8}$ as well as in the solid state ${ }^{9}$, the 1, 3-diones exists almost exclusively as keto-enol tautomer. Recently it is reported that 1, 3-dionesare important pharmacophores of HIV-1 integrase $(1 \mathrm{~N})$ inhibitors ${ }^{10}$. It was also reported that a number of diketones has warrant examination as breast cancer chemo preventive blocking agent ${ }^{11}$ anticarcinogenic agent ${ }^{12}$ and antistereogenic agent ${ }^{13}$. 
1, 3-Diones and its metal complexes appear very promising for potential use as antibacterial agents due to their other biological properties ${ }^{14-17}$. There is continue interest in synthesizing 1, 3-diones $\mathbf{4}\left(\mathbf{L}_{\mathbf{A}}-\mathbf{L}_{\mathbf{B}}\right)$ and its metal complexes $\mathbf{5}(\mathbf{a}-\mathbf{e})$ because of their potential applications, applied sciences and importance area of coordination chemistry ${ }^{18-21}$. The synthesized ligands and its transition metal complexes have been screened for in vitro antibacterial activity against $S$. aureus, $B$. subtilis, E. coli and $P$. aeruginosacompared with tetracycline and chloramphenicol as standard drugs.

\section{Experimental}

All chemicals used were of the analytical grade (AR) and of highest purity. IR spectra in the range 4000-400 $\mathrm{cm}^{-1}$ were recorded on Shimadzu FT-IR-4100 spectrometer using $\mathrm{KBr}$ pallets. ${ }^{1} \mathrm{H}$-NMR and ${ }^{13} \mathrm{C}$-NMR spectra of the ligand were recorded in $\mathrm{CDCl}_{3}$ solvent. Mass spectra were taken on a Macro Mass spectrometer. The UV-Vis spectra of the complexes were recorded on Shimadzu UV-1800 Spectrophotometer. Magnetic measurements of the metal complexes were done on a Gouy balance at room temperature using $\mathrm{Hg}\left[\mathrm{Co}(\mathrm{SCN})_{4}\right]$ as a calibrant. The antibacterial activity was carried out by spectroscopic method using DMSO solvent.

\section{Synthesis of 2-acetylphenylbenzoate $\mathbf{3}(\boldsymbol{A}-\boldsymbol{B})$}

Substituted 2-hydroxyacetophenones 1(A-B) and aromatic acid 2(A-B) were dissolved in $15 \mathrm{~mL}$ dry pyridine. The reaction mixture was then cooled to $0{ }^{\circ} \mathrm{C}$. To this, phosphorus oxychloride $(0.06 \mathrm{~mol})$ was added drop wise maintaining temperature below $10{ }^{\circ} \mathrm{C}$. Then the reaction mixture was irradiated for about $2-3 \mathrm{~h}$. It was then poured into $100 \mathrm{~mL} 1 \mathrm{M} \mathrm{HCl}$ containing $50 \mathrm{~g}$ crushed ice with vigorous stirring. The crimson colored solid was obtained which was filtered and washed several times with ice cold water. Compound 3(A-B) was then recrystallized with distilled ethanol. Purity of the compound was checked by TLC. The compound 3(A-B) was subjected to well known Baker-Venkatraman transformation.

Synthesis of (Z)-1-(5-bromo-2-hydroxyphenyl)-3-(4-fluorophenyl)-3-hydroxy prop-2-en-1one) $\mathbf{4}\left(\mathbf{L}_{\mathrm{A}}\right)$

A compound containing $\mathbf{3}(\mathbf{A}) 3.18 \mathrm{~g}, 0.01 \mathrm{~mol}$ ) was dissolved in $15 \mathrm{~mL}$ dry pyridine. To this mixture, powdered $\mathrm{KOH}(1.12 \mathrm{~g}, 0.02 \mathrm{~mol})$ was irradiated for about $1-2 \mathrm{~h}$. Then it was poured over crushed ice and acidified with concentrated hydrochloric acid. The resulting solid $\mathbf{4}\left(\mathbf{L}_{\mathbf{A}}\right)$ was recrystallized from ethanol (Yield: $80 \%$, Table 1); m.p.:172 ${ }^{\circ} \mathrm{C}$. Anal. Calcd (\%) for $\mathrm{C}_{15} \mathrm{H}_{10} \mathrm{BrFO}_{3}$ (Molecular weight=337.14 g. mol ${ }^{-1}$ ) C, 53.44; H, 2.99; Br, 23.70; F, 5.64; O, 14.24. IR (KBr) $v_{\max } / \mathrm{cm}^{-1} ; 1744(v(\mathrm{C}=\mathrm{O})$ ketonic), 1178 ( $(\mathrm{C}(\mathrm{C}-\mathrm{O})$ enolic), 3109 ( $\mathrm{v}(-$ $\mathrm{OH})$ intramolecular H-bonding in Phenolic). ${ }^{1} \mathrm{H}-\mathrm{NMR}\left(500 \mathrm{MHz}, \mathrm{CDCl}_{3}-\mathrm{d}_{6}\right) ; \delta / \mathrm{ppm}=$ $15.56(\mathrm{~s}, 1 \mathrm{H}$, enolic $-\mathrm{OH}), 12.02(\mathrm{~s}, 1 \mathrm{H}$, Phenolic $-\mathrm{OH}), 7.55(\mathrm{~s}, 1 \mathrm{H},=\mathrm{C}-\mathrm{H}$ ethylene $), 6.72-$ $8.02(\mathrm{~m}, 7 \mathrm{H}, \mathrm{Ar}-\mathrm{H}) .{ }^{13} \mathrm{C}-\mathrm{NMR}\left(500 \mathrm{MHz}, \mathrm{CDCl}_{3}\right) \delta / \mathrm{ppm}=194.17(\mathrm{C}=\mathrm{O}), 177.35(\mathrm{C}-\mathrm{O}$ enolic), 91.85 (=C-H ethylene). UV/Vis. (DMSO) nm: 371, 256. MS m/z: 337.98.

Synthesis of (Z)-3-hydroxy-1-(2-hydroxyphenyl)-3-(4-nitrophenyl) prop-2-en-1one) $\mathbf{4}\left(\mathrm{L}_{\mathrm{B}}\right)$

A compound containing $\mathbf{3 ( B )}$ (3 g, $0.01 \mathrm{~mol}$ ) was dissolved in $15 \mathrm{~mL}$ dry pyridine. To this mixture, powdered $\mathrm{KOH}(1 \mathrm{~g}, 0.02 \mathrm{~mol})$ was irradiated for about $1-2 \mathrm{~h}$. Then it was poured over crushed ice and acidified with concentrated hydrochloric acid. The resulting solid $\mathbf{4}\left(\mathbf{L}_{\mathbf{B}}\right)$ was recrystallized from ethanol (Yield: 82\%); m.p.:132 ${ }^{\circ} \mathrm{C}$. Anal. Calcd (\%) for $\mathrm{C}_{15} \mathrm{H}_{11} \mathrm{NO}_{5}$ $\left(\mathrm{MW}=285.06 \mathrm{~g} . \mathrm{mol}^{-1}\right) \mathrm{C}, 63.16 ; \mathrm{H}, 3.99 ; \mathrm{N}, 4.91 ; \mathrm{O}, 28.04$. IR $(\mathrm{KBr}) v_{\max } / \mathrm{cm}^{-1} ; 1735$ 
$(v(\mathrm{C}=\mathrm{O})$ ketonic $), 1199(v(\mathrm{C}-\mathrm{O})$ enolic $), 3099(v(-\mathrm{OH})$ intramolecular H-bonding in Phenolic). ${ }^{1} \mathrm{H}-\mathrm{NMR}\left(500 \mathrm{MHz}, \mathrm{CDCl}_{3}-\mathrm{d}_{6}\right) ; \delta / \mathrm{ppm}=14.80(\mathrm{~s}, 1 \mathrm{H}$, enolic $-\mathrm{OH}), 11.87$ (s, 1H, Phenolic -OH) 7.49 (s, 1H, =C-H ethylene), 6.54-7.98 (m, 8H, Ar-H); UV/Vis. (DMSO) nm: 399, 340. MS m/z: 285.06.

\section{Synthesis of metal complexes 5(a-e)}

A hot ethanolic solution, $25 \mathrm{~mL}$ of ligand $\left(\mathbf{4} \mathbf{L}_{\mathbf{A}}\right)(0.002 \mathrm{M})$ and a hot ethanolic solution, $25 \mathrm{~mL}$ of required metal salt $(0.001 \mathrm{M})$ were irradiated for about 90 minute under ultrasound. Then a colored solid 5(a-e) precipitate formed was filtered, washed with cold ethanol and dried under vacuum. All complexes were colored solids and air stable. (Yield: $82-87 \%$ ) m. p. $\geq 300{ }^{\circ} \mathrm{C}$.

Anal. Calcd. (\%) for 5(a) $\mathrm{C}_{30} \mathrm{H}_{22} \mathrm{Br}_{2} \mathrm{~F}_{2} \mathrm{MnO}_{8}\left(\mathrm{MW}=763.23\right.$ g.mol $\left.{ }^{-1}\right) \mathrm{C}, 47.21 ; \mathrm{H}, 2.91$; $\mathrm{Br}, 20.94 ; \mathrm{F}, 4.98$; O, 16.77; Mn, 7.20; IR (KBr) $v_{\max } / \mathrm{cm}^{-1} ; 1649(v(\mathrm{C}=\mathrm{O})$ ketonic $), 1143$ $(v(\mathrm{C}-\mathrm{O})$ enolic), $3072(v(-\mathrm{OH})$ intramolecular H-bonding in Phenolic), $3433(v(-\mathrm{OH})$ in $\mathrm{H}_{2} \mathrm{O}$ molecules) 515 ( $v\left(\mathrm{M}-\mathrm{O}\right.$ bond in complex); UV/Vis. (DMSO) nm: $271\left(\pi \rightarrow \pi^{*}\right), 398$ (LMCT); $\mu$ eff (BM):5.86.

Anal. Calcd. (\%) for 5(b) $\mathrm{C}_{30} \mathrm{H}_{22} \mathrm{Br}_{2} \mathrm{~F}_{2} \mathrm{FeO}_{8}\left(\mathrm{MW}=764.14\right.$ g. mol- $\left.{ }^{1}\right) \mathrm{C}, 47.15 ; \mathrm{H}, 2.90$; $\mathrm{Br}, 20.91$; F, 4.97; O, 16.75. Fe, 7.31; IR (KBr) $v_{\max } / \mathrm{cm}^{-1} ; 1647$ ( $v(\mathrm{C}=\mathrm{O})$ ketonic), $1145(v$ (C-O) enolic), $3070\left(v(-\mathrm{OH})\right.$ intramolecular H-bonding in Phenolic), $3367\left(v(-\mathrm{OH})\right.$ in $\mathrm{H}_{2} \mathrm{O}$ molecules), 526 ( $v\left(\right.$ M-O bond in complex); UV/Vis. (DMSO) $\mathrm{nm}: 272\left(\pi \rightarrow \pi^{*}\right), 397$ (LMCT), 672 (d-d); $\mu$ eff (BM):6.33.

Anal. Calcd. (\%) for 5@ $\mathrm{C}_{30} \mathrm{H}_{22} \mathrm{Br}_{2} \mathrm{~F}_{2} \mathrm{CoO}_{8}\left(\mathrm{MW}=767.23\right.$ g. mol- ${ }^{1}$ ) C, 46.96; H, 2.89; $\mathrm{Br}, 20.83$; F, 4.95; O, 16.68. Co, 7.68; IR (KBr) $v_{\max } / \mathrm{cm}^{-1} ; 1645(v(\mathrm{C}=\mathrm{O})$ ketonic), $1147(v$ (C-O) enolic), $3070\left(v(-\mathrm{OH})\right.$ intramolecular H-bonding in Phenolic), $3464\left(v(-\mathrm{OH})\right.$ in $\mathrm{H}_{2} \mathrm{O}$ molecules), 522 ( $v\left(\right.$ M-O bond in complex); UV/Vis. (DMSO) $\mathrm{nm}: 270\left(\pi \rightarrow \pi^{*}\right), 392$ (LMCT), 674 (d-d); $\mu$ eff (BM):4.26.

Anal. Calcd. (\%) for 5(d) $\mathrm{C}_{30} \mathrm{H}_{22} \mathrm{Br}_{2} \mathrm{~F}_{2} \mathrm{NiO}_{8}\left(\mathrm{MW}=766.99\right.$ g. mol- $\left.{ }^{1}\right) \mathrm{C}, 46.98 ; \mathrm{H}, 2.89$; $\mathrm{Br}, 20.84 ; \mathrm{F}, 4.95 ; \mathrm{O}, 16.69$. Ni, 7.65; IR (KBr) $v_{\max } / \mathrm{cm}^{-1} ; 1645(v(\mathrm{C}=\mathrm{O})$ ketonic), $1143(v$ (C-O) enolic), $3072\left(v(-\mathrm{OH})\right.$ intramolecular H-bonding in Phenolic), $3450\left(v(-\mathrm{OH})\right.$ in $\mathrm{H}_{2} \mathrm{O}$ molecules), 526 ( $v\left(\mathrm{M}-\mathrm{O}\right.$ bond in complex); UV/Vis. (DMSO) $\mathrm{nm}: 271\left(\pi \rightarrow \pi^{*}\right), 401$ (LMCT), 674 (d-d); $\mu$ eff (BM):2.50.

Anal. Calcd. (\%) for 5(e) $\mathrm{C}_{30} \mathrm{H}_{22} \mathrm{Br}_{2} \mathrm{~F}_{2} \mathrm{CuO}_{8}\left(\mathrm{MW}=771.84\right.$ g. mol- ${ }^{1}$ ) C, 46.68; H, 2.87; $\mathrm{Br}, 20.70 ; \mathrm{F}, 4.92 ; \mathrm{O}, 16.58 . \mathrm{Cu}, 8.23$; IR $(\mathrm{KBr}) v_{\max } / \mathrm{cm}^{-1} ; 1648(v(\mathrm{C}=\mathrm{O})$ ketonic $), 1149(v$ (C-O) enolic), $3030\left(v(-\mathrm{OH})\right.$ intramolecular H-bonding in Phenolic), $3426\left(v(-\mathrm{OH})\right.$ in $\mathrm{H}_{2} \mathrm{O}$ molecules), 513 ( $v\left(\right.$ M-O bond in complex); UV/Vis. (DMSO) $\mathrm{nm}: 276\left(\pi \rightarrow \pi^{*}\right), 393$ (LMCT), 673 (d-d); $\mu$ eff (BM):2.1.

\section{Results and Discussion}

1, 3-Diketone was prepared by the esterification of substituted 2-hydroxy acetophenones 1(A-B) with aromatic acid 2(A-B) in presence of $\mathrm{POCl}_{3}$ (Scheme 1) to offer yellow solid $\mathbf{4}\left(\mathbf{L}_{\mathbf{A}}-\mathbf{L}_{\mathbf{B}}\right)$. All the complexes $\mathbf{5}(\mathbf{a}-\mathbf{e})$ were colored solids, air stable and soluble in polar solvents like DMF and DMSO. The elemental analysis show 1:2 (metal: ligand) stoichiometry for all the complexes. The structure of the compounds characterized by spectral analysis. The magnetic measurement studies showed that the complexes $\mathbf{5}(\mathbf{a}-\mathbf{e})$ have octahedral geometry ${ }^{22}$. All complexes showed higher antibacterial activity than the free ligands. 


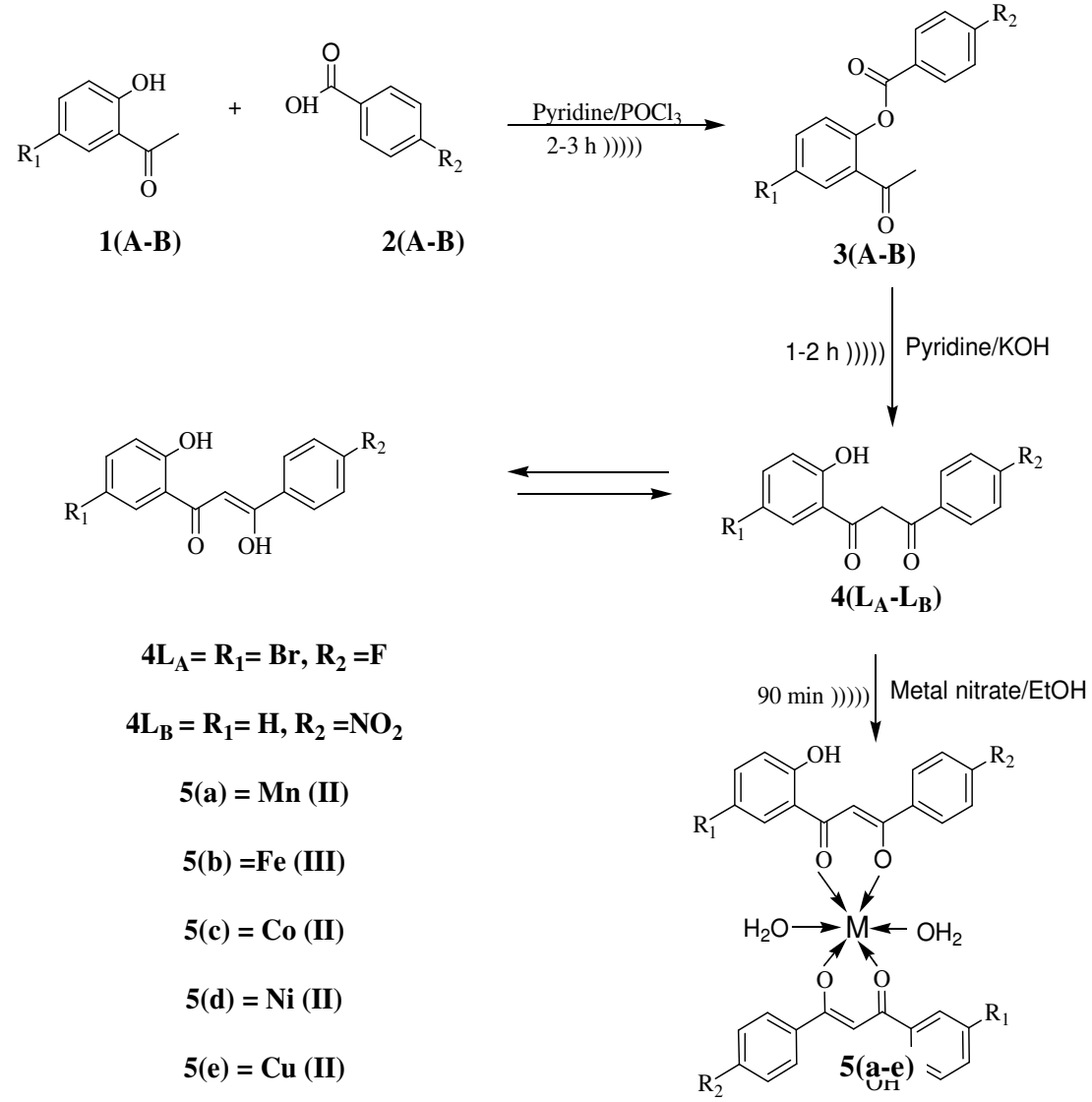

Scheme 1. Synthesis of ligands and its metal complexes

Table 1. Physical characterization and ultrasonic study of ligand and its metal complexes

\begin{tabular}{|c|c|c|c|c|c|c|}
\hline \multirow{2}{*}{$\begin{array}{l}\text { Ligand/ } \\
\text { Complexes }\end{array}$} & \multirow{2}{*}{$\begin{array}{c}\text { MW } \\
\text { (Mol.Wt.) }\end{array}$} & \multirow{2}{*}{$\begin{array}{l}\text { M.P./decomp. } \\
\text { temp }\left({ }^{0} \mathrm{C}\right)\end{array}$} & \multicolumn{2}{|c|}{ Conventional } & \multicolumn{2}{|c|}{$\begin{array}{l}\text { Ultrasound } \\
\text { Irradiation }\end{array}$} \\
\hline & & & Time, $\min$ & Yield, \% & Time, min & Yield, \% \\
\hline $4 L_{A}$ & 337.14 & 172 & 370 & 68 & 120 & 80 \\
\hline 4LB & 285.25 & 132 & 370 & 70 & 120 & 82 \\
\hline $5 \mathbf{a}$ & 763.23 & $\geq 300$ & 280 & 72 & 90 & 82 \\
\hline $5 \mathbf{b}$ & 764.14 & $\geq 300$ & 280 & 68 & 90 & 80 \\
\hline $5 c$ & 767.23 & $\geq 300$ & 280 & 70 & 90 & 85 \\
\hline $5 d$ & 766.99 & $\geq 300$ & 280 & 73 & 90 & 84 \\
\hline $5 e$ & 771.84 & $\geq 300$ & 280 & 74 & 90 & 87 \\
\hline
\end{tabular}

Magnetic measurements

The magnetic measurements of complexes were measured at room temperature. The observed magnetic moment value of (5a) complex is $5.86 \mathrm{BM}$, (5b) complex is $6.33 \mathrm{BM}$, 5c) complex is $4.26 \mathrm{BM},(\mathbf{5 d})$ complex is $2.50 \mathrm{BM}$, and (5e) complex is $2.12 \mathrm{BM}$. The magnetic measurement studies showed that the all complexes have octahedral geometry ${ }^{23-26}$. 


\section{Spectroscopic analysis}

The ${ }^{1} \mathrm{H}$-NMR spectrum of the compound $\mathbf{4}\left(\mathbf{L}_{\mathbf{A}}-\mathbf{L}_{\mathbf{B}}\right)$ exhibited a singlet at $\delta 15.56$ and 14.80 ppm due to enolic proton a singlet at $\delta 12.02$ and $11.87 \mathrm{ppm}$ due to phenolic proton adjacent to the carbonyl group and a singlet at $\delta 7.55$ and $7.49 \mathrm{ppm}$ respectively showed ethylene proton indicate that keto- enol form in 1,3-diketone is more stable. The characteristics infrared spectral assignment of ligand $\mathbf{4}\left(\mathbf{L}_{\mathbf{A}}-\mathbf{L}_{\mathbf{B}}\right)$ and their metal complexes $\mathbf{5}(\mathbf{a}-\mathbf{e})$ the presence of broad band at 3109 and $3099 \mathrm{~cm}^{-1}$ exhibited intramolecular hydrogen bonding due to $-\mathrm{OH}$ group. All the above evidences were further supported by the emergence of new bands at $515-526 \mathrm{~cm}^{-1}$ due to metal-oxygen vibrations. These new bands observed in the spectra of the transition metal complexes and not in ligands.

\section{Antibacterial activity}

Two Gram-positive (B. subtilis NCIM 2063 and S. aureus NCIM 2079) and two Gramnegative (E. coli NICM 2065 and P. aeruginosa NCIM 2200) bacteria were used as test organisms. The positive control drug tetracycline and chloramphenicol were dissolved in DMSO at a concentration of $1 \mathrm{mg} / \mathrm{mL}$. Antibacterial activities of the bacterial strains were carried out in nutrient broth with inoculums of $10^{3}$ cells $\mathrm{ml}^{-1}$ by the spectroscopic method and an aliquot of $30 \mu \mathrm{L}$ was added to each tube of the serial dilution. The chemical compounds were added in nutrient broth medium with bacterium and incubated on a rotary shaker at $37{ }^{\circ} \mathrm{C}$ for $24 \mathrm{~h}$ at $150 \mathrm{rpm}$. The percentage growth was calculated by the following equation $^{27}$.

$$
\% \text { Grouth }=(\mathrm{OD} \text { at } 600 \mathrm{~nm} \text { sample }) /(\mathrm{OD} \text { at } 600 \mathrm{~nm} \text { control }) \times 100
$$

Compound $\mathbf{4} \mathbf{L}_{\mathbf{A}}$ showed maximum growth inhibitory effect on E. coli and B. subtilis as compared to $S$. aureus and $P$. aeruginosa at $25 \mathrm{ppm}$ concentration. Amongst the Samples 5(a-e) only sample 5d exhibited the growth inhibitory action on E.coli, B.subtilis and P. aeruginosa at lower concentration of $20 \mathrm{ppm}$. Remaining all samples did not showed any growth reduction of other bacteria except $S$. aureus at $50 \mathrm{ppm}$ concentration. The $\mathrm{Ni}(\mathrm{II})$ complex $\mathbf{5 d}$ has found to be more promising compared to other metal complexes. From the Table 2 it is clear that, the results are in good agreement with respect to activity of free ligand and its metal complexes ${ }^{28,29}$.

Table 2. MIC of ligand and its metal complexes for antibacterial activity

\begin{tabular}{ccccc}
\hline Samples & $\begin{array}{c}\text { E.coli(NCI } \\
\text { M 2065), } \\
\text { ppm }\end{array}$ & $\begin{array}{c}B . \\
\text { subtilis(NCIM } \\
\text { 2063), } \mathrm{ppm}\end{array}$ & $\begin{array}{c}P . \\
\text { aeruginosa }(\mathrm{NCI} \\
\mathrm{M} 2200), \mathrm{ppm}\end{array}$ & $\begin{array}{c}\text { aureus(NCIM } \\
\text { 2079), } \mathrm{ppm}\end{array}$ \\
\hline $4 \mathrm{~L}_{\mathrm{A}}$ & 25 & 25 & $>50$ & 50 \\
$5 \mathrm{a}$ & $>50$ & 50 & $>50$ & 50 \\
$5 \mathrm{~b}$ & $>50$ & $>50$ & $>50$ & 50 \\
$5 \mathrm{c}$ & $>50$ & $>50$ & $>50$ & 50 \\
$5 \mathrm{~d}$ & 25 & 25 & 20 & 50 \\
$5 \mathrm{e}$ & 50 & $>50$ & $>50$ & 50 \\
Tetracycline & $<10$ & $<10$ & $<10$ & $<10$ \\
Chloramphenicol & $<10$ & $<10$ & $<10$ & $<10$ \\
\hline
\end{tabular}

\section{Conclusion}

In the present work 1-(2-hydroxyphenyl)-3-propane-1, 3-diones $\mathbf{4}\left(\mathbf{L}_{\mathbf{A}}-\mathbf{L}_{\mathbf{B}}\right)$ and its metal complexes 5(a-e) were synthesized and their structures elucidated on the basis of spectral analysis. Ultrasound irradiation assisted organic synthesis is an efficient and eco-friendly 
synthetic strategy for improve yields and increases selectivity. Magnetic measurements reveled that all complexes possessed octahedral geometry. The synthesized ligand $\mathbf{4}\left(\mathbf{L}_{\mathbf{A}}-\mathbf{L}_{\mathbf{B}}\right)$ having $\mathrm{O}, \mathrm{O}$ pharmacophores site played an important role to increased antibacterial activity. All these metal complexes were more potent antibacterial activities than the parent ligands. Thus it is concluded that the compounds were found to possess a broad range of hydrophilic and lipophilic characters, hence indication of favorable bioavailability based on drug likeness.

\section{Acknowledgment}

The authors are grateful to the Head, Department of Chemistry, Dr. Babasaheb Ambedkar Marathwada University, Aurangabad and UGC-SAP-DRS Scheme 1, for providing necessary laboratory facilities, Department of Chemistry, Savitribai Phule Pune University, for providing laboratory facilities for carried out antibacterial screening, Department of Chemistry, Annasaheb Awate College, Manchar and UGC (WRO) Pune for providing Teacher fellowship under FIP.

\section{References}

1. Bennett I, Broom N J P, Cassels R, Elder J S, Masson N D and O'Hanlon P J, Med Chem Lett., 1999, 9(13), 1847-1852; DOI:10.1016/S0960-894X(99)00296-6

2. Diana G D, Carabateas P M, Johnson R E, Williams G L, Pancic F and Collins J C, $J$ Med Chem., 1978, 21(9), 889-894; DOI:10.1021/jm00207a010

3. Crouse G D, McGowan M J and Boisvenue R J, J Med Chem., 1989, 32(9), 21482151; DOI:10.1021/jm00129a021

4. Nishiyama T, Shiotsu S and Tsujita H, Polym Degrad Stab., 2002, 76(3), 435-439; DOI:10.1016/S0141-3910(02)00046-0

5. Acton N, Brossi A, Newton D L and Sporn M B, J Med Chem., 1980, 23, 805-809.

6. Sheikh J, Ingle V and Juneja H, E J Chem., 2009, 6, 705-712.

7. Andrae I, Bringhen A, Bohm F, Gonzenbach H, Hill T, Mulroy L and Truscott T G, $J$ Photochem Photobiol B Biol., 1997, 37(1-2), 147-150; DOI:10.1016/S10111344(96)07330-7

8. Tobita S, Ohba J, Nagakawa K and Shizuka H, J Photochem A: Chem., 1995, 92(1-2), 61-67; DOI:10.1016/1010-6030(95)04158-X

9. Kaitner B and Mestrovic E, Acta Crystallogr C, 1993, 49, 1523-1525; DOI:10.1107/S0108270193001787

10. Tchertanov L and Mouscadet J F, J Med Chem., 2007, 50(6), 1133-1145; DOI:10.1021/jm061375j

11. Chate A V, Joshi R S, Badadhe V and Gill C H, Bull Korean Chem Soc., 2011, 32(11), 3887-3892; DOI:10.5012/bkcs.2011.32.11.3887

12. Singh K, Barwa M S and Tyagi P, Eur J Med Chem., 2006, 41(1), 147-153; DOI:10.1016/j.ejmech.2005.06.006

13. Oluwatola Omoregie, International J Chem., 2011, 3(1); DOI:10.5539/ijc.v3n1p24

14. Sing D P, Kumar R, Malik V and Tagi P, J Enzyme Inhib Med Chem., 2007, 22(2), 177-182; DOI:10.1080/14756360601051399

15. EI-Waheb Z H A, J Coord Chem., 2009, 43, 231.

16. Chandra S, Tyagi M and Agrawal S, J Serb Chem Soc., 2010, 75(7), 935-941; DOI:10.2298/JSC090804069C

17. Hunter T M, Paisey S J and Park H S, J Inorg Biochem., 2004, 98(5), 713-719; DOI:10.1016/j.jinorgbio.2003.10.018 
18. Dier V, Cuevas J V, Herbosa G G, Aullon G, Charwant J P H, Carbayo A and Munoz A, Inorg Chem., 2007, 46(2), 568-577; DOI:10.1021/ic061060u

19. Salavati-Naissari M, Adaryni M R and Heydarzadeh S, Transition Met Chem., 2005, 30(4), 445-450; DOI:10.1007/s11243-005-1017-2

20. Sangputa P, Dinda R, Ghosh S and Sheldrick W S, Polyhedron, 2003, 22(2), 477-483; DOI:10.1016/j.poly.2005.07.025

21. Leelavathy L, Anbu S, Kandaswamy M, Karthikeyan N and Mohan N, Polyhedron,2009, 28(5), 903-910; DOI:10.1016/j.poly.2008.12.062

22. Chohan Z H, Arif M, Akhtar M A and Supuran C T, J Bioinorganic Chemistry Applications, 2006, Article ID 83131, 13 pages; DOI:10.1155/BCA/2006/83131

23. Korde N S, Gaikwad S T, Khade B C and Rajbhoj A S, Chem Sci Trans., 2013, 2(2), 407-412; DOI:10.7598/cst2013.355

24. Nanda S Korde, Suresh T Gaikwad, Seems S Korde and Anjali S Rajbhoj, J Rec Tech Engin., 2013, 2, 4

25. Kumar U and Chandra S, J Saudi Chem Soc., 2011, 15(2), 187-193; DOI:10.1016/j.jscs.2010.08.002

26. Revankar V K and Mahale V B, Indian J Chem A, 1979, 28, 683-688.

27. Satyajit D Sarker, Lutfun Nahar and Yashodharan Kumarasamy, Phytochem., 2007. 42, 321-324; DOI:10.1016/j.ymeth.2007.01.006

28. Mohanan K and Devi S N, Russ J Coord Chem., 2006, 32(8), 600-609; DOI:10.1134/S1070328406080124

29. Mane P S, Shirodkar S G, Arbad B R and Chondhekar T K, Indian J Chem., 2001, 40 648-651. 